\title{
Yhteistyö ja verkostoituminen maitotiloilla
}

\author{
Erkki Laitila $^{1)}$, Matti Ryhänen ${ }^{1)}$, Margit Närvä ${ }^{1)}$ ja Timo Sipiläinen ${ }^{2)}$ \\ ${ }^{1)}$ Seinäjoen ammattikorkeakoulu, SeAMK Elintarvike ja maatalous, Ilmajoentie 525, 60800 Ilmajoki, \\ etunimi.sukunimi@seamk.fi \\ ${ }^{2)}$ Helsingin yliopisto, taloustieteen laitos, PL 27, 00014 Helsingin yliopisto, \\ timo.sipilainen@helsinki.fi
}

\section{Tiivistelmä}

Strategisen päätöksenteon merkitys maitotiloilla korostuu markkinaohjautuvuuden kasvun myötä. Tässä tutkimuksessa yhteistyötä ja verkostoitumista tarkastellaan strategisen päätöksenteon näkökulmasta. Strategisessa yhteistyössä omien tavoitteiden saavuttaminen ei ole mahdollista ilman kumppaneiden panosta. Strategisen yhteistyön toteuttamista selvitettiin osanottajien ja yhteistyösuhteen organisoitumisen näkökulmista säilörehun tuotannossa, hiehonkasvatuksessa ja navettayhteistyössä, jotka kuvaat yhteistyön syvyyden eri tasoja.

Tutkimusaineisto kerättiin haastattelemalla maidontuottajia, joilla yhteistyö on liiketoiminnan tärkeä lähtökohta. Tutkimusaineisto koostuu viidestä eri teemahaastatteluaineistosta, joista yksi käsittelee säilörehunkorjuuta, kaksi hiehonkasvatusta ja kaksi yhteisnavettaa. Laadullis-induktiivista analyysiä käyttäen tavoitteena oli tehdä yleistyksiä ja tulkintaa aineistosta esiin nousevien seikkojen perusteella. Tulokset eivät ole yleistettävissä, mutta ne ovat siirrettävissä koskemaan tutkimusaineistoa suurempaa tilajoukkoa.

Tilayhteistyönä toteutettavan säilörehunkorjuun perustana ovat yhteiset tavoitteet kuten yksikkökustannusten alentaminen, pääoman määrän vähentäminen, lyhytaikaisen työvoimatarpeen ratkaiseminen ja hyvälaatuinen rehu. Yhteistyö toteutetaan joko yhteisin konein tai osallistujien omilla koneilla. Strategisessa urakointiyhteistyössä on maitotilan näkökulmasta tarkasteltuna samat tavoitteet.

Hiehonkasvatusyhteistyö on strategista yhteistyötä, jossa maitotila luovuttaa hiehonkasvatuksen kokonaan tai osittain toisen yrittäjän hoidettavaksi. Tavoitteena on yleensä lehmäpaikkojen lisääminen, rehualan käyttö lehmille, työmäärän vähentäminen ja hiehonkasvattajan osaamisen hyödyntäminen. Hiehonkasvattajan näkökulmasta oleellista on kapasiteetin käyttöasteen pitäminen korkeana ja tasaisena. Yhteistyön organisoinnin kannalta oleellisimpia kysymyksiä ovat tiineyttäminen, jalostusprosessin ylläpito, siirtojen organisointi kustannustehokkaasti ja eläintautiriskin hallinta.

Navettayhteistyöllä tarkoitetaan yhteistyösuhdetta, jossa maidontuottajat luopuvat omasta maidontuotannosta ja perustavat yhteisen yrityksen. Keskeiset syyt ovat yksikkökustannusten alentaminen, riskien jakaminen, työmäärän alentaminen, vapaa-ajan kasvu ja osaamisen hyödyntäminen. Yhteistyö voidaan organisoida niin, että rakennetaan uusi navetta, eläimet siirretään navettayhtiön omistukseen ja osanottajien pellot vuokrataan navettayhtiölle. Osanottajat toimivat yhteisnavetan työntekijöinä.

Tulosten mukaan yhteistyö ja verkostoituminen tuovat kilpailuetua siihen verrattuna, että maidontuottaja toimisi yksin. Keskittyminen ydinosaamiseen, ulkoistaminen, verkostoituminen ja muut yritysten väliset liittoumat ovat tulossa osaksi strategista ajattelua ja suunnittelua. Näillä toimilla säästetään työ- ja pääomakustannuksissa. Yhteistyö mahdollistaa myös teknologian kehittymisestä saatavan edun hyödyntämisen ja tuottavuuden parantamisen.

Asiasanat: yhteistyö, strategia, teemahaastattelu, maidontuotanto, säilörehuntuotanto, hiehonkasvatus 


\section{Johdanto}

Maidontuottajien toimintaympäristö on voimakkaassa muutoksessa, kun maatalouspolitiikkaa uudistetaan ja markkinaohjautuvuus kasvaa. Strategisen ajattelun ja suunnittelun merkitys korostuu, kun maitotilan kilpailukykyä parannetaan. Verkostomainen yrittäminen, johon kuuluvat mm. erilaiset kumppanuussuhteet, yhteistyömuodot ja urakointipalvelut, mahdollistaa yksikkökustannusten alentamisen ja taloudellisen tuloksen parantamisen ja voi olla vastaus kehittämishaasteeseen. Tekninen kehitys kannustaa maidontuottajaa hakemaan uusia toimintatapoja yritystoiminnan kehittämiseen. Myös resurssien käyttöä on muutettava (Öhlmer ym. 1993).

Verkostomainen toimintatapa tarkoittaa yritystoimintaa, jossa yrityksen prosesseja toteutetaan yhteistyönä. Prosessimainen ajattelutapa mahdollistaa kokonaisprosessin jakamisen osiin, jolloin osaprosessin toteutus tai ulkoistaminen yritysten yhteistyönä voidaan toteuttaa kokonaisprosessia tukevalla tavalla (vrt. esim. SFS-EN ISO9001). Tällaisen toimintamallin rakentaminen ja tehokas ylläpito edellyttävät, että yrityksen strateginen ajattelutapa tukee verkostoitumista. Lisäksi onnistuminen edellyttää, että yrityksessä, osana sen strategista ajattelua, on omaksuttu prosessimainen ajattelutapa, jolloin tuotannontekijöiden yhdistäminen tuotteiksi ymmärretään toimintojen ketjuina, joiden lopputuloksina ovat asiakkaiden vaatimukset täyttävät tuotteet.

Yhteistyötä voidaan laajentaa ja syventää eri osapuolten ja tuotantosuuntien välillä sekä toimintoja uudelleen järjestelemällä. Keskittyminen ydinosaamiseen, toimintojen ulkoistaminen, verkottuminen ja osaamisen jakaminen mahdollistavat kilpailukyvyn parantamisen (Ryhänen ym. 2011, 72). Kaikkia yhteistyöosapuolia hyödyttävän verkostomaisen toiminnan onnistuminen ja yhteistyösuhteiden säilyttäminen edellyttävät yhteistyötä tukevan ja luottamukseen perustuvan asenneilmapiirin synnyttämistä sekä lisäämistä yhteistyöverkostossa (Ståhle-Laento 2000, 52-56; Blomqvist 2002,152156). Yhteistyön onnistuminen edellyttää myös johtamisjärjestelmän ja toteutuksen kehittämistä tasolle, jossa yhteistyön taloudelliset ja tuotannolliset reunaehdot voidaan luotettavasti selvittää ja toteuttaa niin, että syntyy kaikkia osapuolia taloudellisesti hyödyttävä toimintamalli (esim. Johnson ym. 2008, 360-365; Hakanen ym. 2007, 55-58; Möller ym. 2004, 28-30; Uotila 1989, 19). Maidontuotannossa kilpailustrategiana on kustannusjohtajuus, jolloin verkostohyödyt liittyvät tavallisesti maidontuotannon yksikkökustannuksen alentamiseen ja/tai asiakkaan edellyttämän laadun varmistamiseen.

Artikkelissa selvitetään verkostomaisen yrittämisen lähtökohtia ja edellytyksiä. Painopiste on maidontuottajien strategisten yhteistyösuhteiden analyysissa. Tavoitteena on selvittää, miten maidontuottajat voivat hyödyntää yritystoiminnassaan verkostomaista toimintatapaa. Tutkimuskysymykset kiteytetään seuraavasti:

- Miten yhteistyö on toteutettu maidontuotannon keskeisissä osaprosesseissa?

- säilörehunkorjuu; sitoutumisen aste vaihtelee

- lypsykarjan uudistaminen eli hiehonkasvatus; sitoutumisen aste kasvaa edellisestä

- Miten yhteistyö on toteutettu yhteisnavetassa ja miten siinä on onnistuttu?

- edellyttää yhteisen strategian luontia ja omista luopumista

\section{Aineisto ja menetelmät Yhteistyösuhteiden tutkiminen}

Yhteistyötä voidaan tehdä monella tasolla. Maidontuottaja, jonka strategisessa ajattelussa korostuu itse tekeminen ja resurssien pitäminen omassa omistuksessa tai hallinnassa, ei välttämättä pidä verkostomaiseen liiketoimintaan perustuvaa mallia edes mahdollisena tai tavoiteltavana. Tällöin ulkoistaminenkin on lähinnä kapasiteettialihankintaa, jossa kilpailutetaan alihankkijat tapauskohtaisesti. Yhteistyön syventyessä osapuolten strateginen riippuvuus toisistaan kasvaa (esim. Hakanen ym. 2007, 5558, Vesalainen 2007, 8-21). Kun yhteistyö syvenee tasolle, jolloin omien strategisten tavoitteiden saavuttaminen ei ole mahdollista ilman yhteistyökumppanien panosta, strateginen yhteistyö on aloitettu. 
Yhteistyösuhteita analysoidaan kuviossa 1 esitetyn viitekehyksen avulla osanottajien näkökulmasta, kumppanuussuhteen järjestämisen näkökulmasta tai molemmat näkökulmat yhdistäen ${ }^{1}$. Osanottajien näkökulmasta (kuvion 1 yläosa) yhteistyösuhteita tarkasteltaessa painotetaan osanottajien verkostoitumisen avulla toteuttamia liiketoiminnallisia tavoitteita ja valittujen toimintamallien perusteluja, yhteistyön organisoinnin sopivuutta strategisiin tavoitteisiin sekä yhteistyövalmiuksia ja niiden merkitystä.

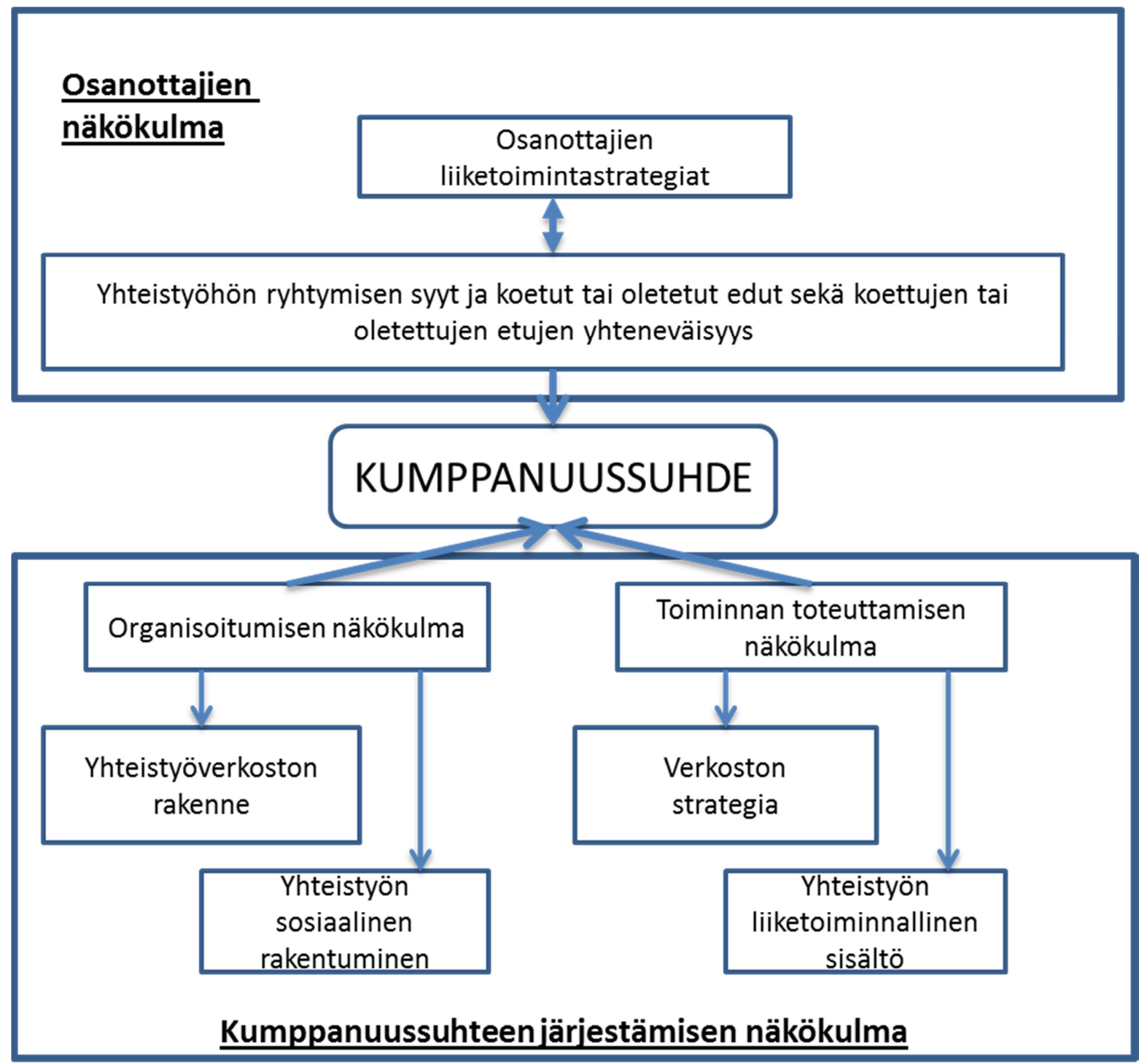

Kuvio 1. Yhteistyösuhteiden analyysin viitekehys.

Kumppanuussuhteen näkökulmasta (kuvion 1 alaosa) yhteistyösuhteita tarkasteltaessa keskitytään yhteistyösuhteen organisoinnin tapaan ja toiminnan toteuttamiseen (vrt. Vesalainen 2002, 58-59). Yhteistyösuhteen organisoinnissa korostuu yhteistyöverkoston rakenne, tapa organisoida yhteistyö. Organisoitumiseen vaikuttaa myös sosiaalinen näkökulma eli miten kumppanit ovat valikoituneet, miten yhteistyön edellyttämä luottamus ja yhteisymmärrys ovat syntyneet ja miten niitä ylläpidetään tai miten yhteistyötä kehitetään (mm. Blomkvist 2002, 154; Laitila ym. 2012, 106-126). Yhteistyön liiketoiminnallisen sisällön analyysissa selvitetään, mihin prosessin osiin kumppanuus kohdistetaan,

\footnotetext{
${ }^{1}$ Osanottajien näkökulman ja kumppanuussuhteen järjestämisen näkökulman erillinen tarkastelu voi johtaa vääriin johtopäätöksiin, sillä ne vaikuttavat toisiinsa.
} 
mitä etuja se tuo tai sen odotetaan tuovan ja mitä operatiivisia toimenpiteitä järjestely osapuolilta edellyttää. Tarkastelu kohdistetaan myös koko verkoston strategiaan (yhteisnavetta).

\section{Aineiston keruun ja analyysin menetelmät}

Koska aiheesta on olemassa vain vähän tutkittua tietoa, kvalitatiivisella tutkimusotteella kartoitettiin tutkittavaa aihealuetta ja haettiin esimerkkejä maitotilojen yhteistyömahdollisuuksista (vrt. Metsämuuronen 2009, 243-246). Aineisto kerättiin teemahaastatteluin. Haastateltavaksi valittiin maidontuottajia, jotka ovat sisällyttäneet yritysten välisen yhteistyön strategiaansa tai ovat asettaneet sen tärkeäksi liiketoiminnan lähtökohdaksi. Yhteistyöhön osallistujien näkökulmaa ja kumppanuussuhteen järjestämisen näkökulmaa tutkittaessa käsitysten, kokemusten ja mielipiteiden tutkiminen on keskeistä. Teemahaastattelu sopii hyvin tällaiseen tutkimusasetelmaan (mm. Hirsjärvi, Remes \& Sajavaara 2007, 160).

Tutkimusaineisto koostuu viidestä teemahaastatteluaineistosta, joista yksi käsittelee säilörehunkorjuuta, kaksi hiehonkasvatusta ja kaksi yhteisnavettaa. Teema-alueet valittiin kuviossa 1 esitetyn viitekehyksen pohjalta. Haastattelijat valmennettiin haastattelua varten ja varmistettiin, että he tuntevat aihepiirin hyvin, jotta haastattelutilanteesta tulee motivoiva, avoin ja keskusteleva. Haastattelut toteutettiin kevään 2011 ja kevättalven 2012 välisenä aikana. Aihepiirit annettiin haastateltavien tietoon, mutta kysymysten muoto ja järjestys muotoutuivat haastattelujen aikana. Kysymykset esitettiin avoimina. Haastateltavilta pyydettiin perusteluja näkemyksille. Haastattelut nauhoitettiin ja haastattelijat tekivät muistiinpanoja.

Säilörehunkorjuun yhteistyöaineisto kerättiin neljällä haastattelulla. Kaksi haastateltua harjoittaa tilojen välistä yhteistyötä yhteisillä koneilla ja kaksi tarjoaa palveluitaan urakointina. Molemmat urakoitsijat tuottavat myös maitoa. Toisella heistä maidontuotanto on pienimuotoista ja urakointi on pääroolissa. Hiehonkasvatusyhteistyöaineisto koostuu seitsemästä maidontuottajan ${ }^{2}$ ja neljästä hiehonkasvattajan haastattelusta. Viittä maidontuottajaa haastateltiin yhteistyösopimusten tarkastelun näkökulmasta. Neljää maidontuottajaa ja neljää hiehonkasvattajaa ${ }^{3}$ haastateltiin yhteistyön strategisesta perustasta sekä yhteistyön organisoinnista. Yhteisnavetta-aineisto koostuu yhdeksästä haastattelusta, joista kahdeksassa haastateltavana oli yksi osakas ja yhdessä kaksi osakasta samanaikaisesti. Yhteisnavetoissa osakkaita on 2-4 ja lypsylehmiä 60-160.

Aineistot litteroitiin haastattelun jälkeen ja analysoitiin litterointien pohjalta. Laadullisinduktiivista analyysiä käyttäen tiivistettiin yhteistyösuhteeseen liittyvät keskeiset tulokset ja etsittiin niille tulkinta (vrt. Hirsjärvi ym. 2007, 160). Tutkimusaineisto hajotettiin aluksi käsitteellisiksi osiksi viitekehyksen mukaisesti (kuvio 1) ja sen jälkeen käsitteelliset osat koottiin synteesin avulla johtopäätöksiksi. Tuloksia ei voida yleistää, mutta ne ovat siirrettävissä koskemaan tutkimusaineistoa laajempaa joukkoa.

\section{Tutkimustulokset}

\section{Säilörehunkorjuun yhteistyö perustuu tilayhteistyöhön tai urakointipalveluun}

Osanottajien näkökulmasta tarkasteltaessa yhteisillä investoinneilla vähennetään koneisiin sitoutuvan pääoman määrää ja lyhytaikaista työvoimatarvetta. Korjuuprosessin sujuvoituminen vähentää myös kustannuksia. Toisaalta rehun D-arvossa voidaan joutua tinkimään. Kumppanuussuhteen järjestämisen näkökulmasta tarkasteltaessa tilayhteistyö oli toteutettu kahden tai kolmen maitotilan välisenä yhteistyönä. Tällöin maidontuottajat omistavat yhdessä säilörehunkorjuukoneita. Koneiden hankintakustannus voidaan jakaa rehunkorjuualan mukaisesti tai sopia muutoin. Työvaiheet voidaan jakaa osakkaiden kesken vastuualueiden mukaisesti tai vaihtoehtoisesti parhaaksi katsotulla tavalla osaprosesseittain. Yhteistyön vahvuutena pidetään työnjakoa. Yhteistyökumppaniin luotetaan ja toistenkin osakkaiden rehuntekoa pidetään tärkeänä.

Säilörehun korjuujärjestys tiloittain pysyy samana tai vaihtelee vuosittain olosuhteiden mukaisesti. Korjuu voi edetä myös lohko kerrallaan rehun valmistumisjärjestyksen mukaisesti, riippumatta siitä kenen rehua se on. Toiminta tutkituissa tilayhteistyötapauksissa on suurpiirteistä. Liian tarkka laskeminen ja pikkutarkkuus nähdään haitallisena. Yhteistyötä pidetään hyödyllisenä, joten jatkossa sitä voidaan lisätä muissa peltotöissä ja yhteisostoissa. Haastateltujen mukaan taloudellinen ajattelu tukee yhteistyön vientiä navettaan asti.

\footnotetext{
${ }^{2}$ Heistä kahta haastateltiin kaksi kertaa eli molemmista näkökulmista.

${ }^{3}$ He muodostivat teemahaastatteluparit.
} 
Säilörehun korjuun yhteistyö urakointipohjalta voi toteutua joko strategisena yhteistyönä tai alihankintana. Urakoitsija, joka on investoinut voimakkaasti säilörehunkorjuuketjuun strategisen yhteistyön pohjalta, tarjoaa palveluita asiakkaan tarpeiden mukaan yhdestä työvaiheesta kokonaissuoritukseen asti. Urakoitsija tekee asiakkaiden rehua kuin omaansa. Vastuista sovitaan etukäteen ja asiakkaan näkemyksiä kunnioitetaan. Urakoitsijan mukaan asiakkaat hyötyvät urakointipalvelusta niin koneiden, työvoiman kuin osaamisenkin kautta. Asiakkaan on puolestaan huolehdittava, että tehokas korjuu voidaan aloittaa heti urakoitsijan saavuttua tilalle sovittuna aikana. Urakoitsija pitää strategista yhteistyötä pääsääntöisesti onnistuneena ratkaisuna. Edellytyksenä onnistuneelle yhteistyölle on molemminpuolinen joustavuus ja toisen kunnioitus. Myös henkilökemioiden tärkeys tunnistetaan. Urakoitsijalla oleva kokemus ja tietämys auttavat yhteistyön onnistumista.

Alihankintaperiaatteella toimiva maidontuottaja-urakoitsija korjaa ensin säilörehunsa ja sen jälkeen urakoi muille (niitto, paalaus ja käärintä). Säilörehunkorjuukoneiden hankinnan ensisijaisena tavoitteena on ollut oman tilan kehittäminen. Oma säilörehunkorjuu tehostui, kun urakointi mahdollisti tehokkaiden koneiden hankinnan. Urakoinnilla katetaan osa säilörehunkorjuukoneiden hankintakustannuksista. Urakointia ei haluta laajentaa liikaa, ettei oman tilan kehittäminen jää taka-alalle. Asiakkaat käyttävät urakoitsijan palveluita erityisesti kolmannen sadon korjuuseen. Urakoitsija on kokenut yhteistyön positiivisena asiana.

\section{Hiehonkasvatusyhteistyö}

Osanottajien näkökulmassa korostuvat toimijoiden strategiset tavoitteet, kumppanuussuhteen merkitys niiden saavuttamisessa sekä kumppanuuteen ryhtymisen operatiiviset syyt. Kumppanuussuhteen järjestämisen näkökulmassa korostuvat kumppanuussuhteen strategiaan ja käytännön toteutukseen sekä yhteistyön organisointiin ja sosiaaliseen vuorovaikutukseen liittyvät näkökulmat. Maidontuottajalla hiehonkasvatuksen ulkoistamisen keskeinen strateginen lähtökohta on lisätä lypsylehmiä rehu- ja lannanlevitysalan kasvamatta. Samalla tuotannon automaatioastetta nostetaan, jolloin kokonaistyömäärä vähenee aiempaan verrattuna. Hiehonkasvattajan keskeinen strateginen lähtökohta on navettakapasiteetin korkea käyttöaste. Jos hän ottaa vasikoita useilta maitotiloilta, eläintautiriski kasvaa. Tällöin riskinhallinta korostuu ja monimutkaistuu.

Hiehojen kasvattaminen lehmäpaikoilla on kallista ja epätarkoituksenmukaista. Kumppanuussuhteen järjestämisessä maidontuottajat pitävät tärkeänä, että yhteistyöstä ja prosessin eri vaiheiden toteutuksesta sovitaan kirjallisesti, mutta vain raamina. Liian yksityiskohtaista sopimusta tilanteiden vaihtumisen vuoksi ei ole järkevää laatia. Siksi useat haastatellut korostavat luottamuksen tärkeyttä. Tärkeänä pidettiin myös riittävän pitkää sopimuksen irtisanomisaikaa, jotta tarvittaessa kumpikin osapuoli ehtii sopeutua uuteen tilanteeseen.

Ulkoistetun hiehonkasvatuksen prosessi alkaa vasikoiden valinnasta, mutta toteutustapa on tilanne- ja tapauskohtainen eikä yleistä linjaa löydetty. Kun vasikat siirretään tilalta toiselle, eläintautiriskin hallinta on tärkeä osa toimintaa. Kun maidontuottaja ja hiehonkasvattaja muodostavat suljetun piirin, jossa eläimet eivät joudu kosketuksiin muiden tilojen eläinten kanssa, tautiriskin hallinta helpottuu. Eläinten siirtoikään vaikuttaa kuljetusten optimointi. Osa maidontuottajista pitää tärkeänä, että hyvällä hiehonkasvattajalla on maitotilatausta. Hiehonkasvattajat olivat 6-260 km etäisyydellä maitotilasta.

Yhteistyö helpottaa lypsylehmien ja hiehojen ruokintaa. Ruokintaprosessien eriyttämisellä voidaan taloudellista tulosta parantaa. Maitotilalla hiehojen hoito ja kiimantarkkailu jäävät helposti toissijaiseksi työksi. Tiinehtymistä voidaan parantaa, kun kiimantarkkailusta ja tiineyttämisestä vastaa hiehonkasvattaja, jolle se on yksi päätehtävistä. Useimmiten hiehojen siementäminen tapahtuu maitotilalle laaditun jalostussuunnitelman mukaisesti ${ }^{4}$. Oikea-aikaista tiinehtymistä pidetään yhteistyön onnistumisen kriteerinä. Tiinehtymisen viivästyessä kasvatusaika pitenee ja kustannukset kasvavat. Hoitoprosessissa keskeistä on eläinten kasvattaminen maitotilan olosuhteisiin sopeutuviksi lypsylehmiksi.

Useimmiten maidontuottaja maksaa hiehonkasvattajalle korvauksen jokaisesta kasvatuspäivästä. Tiinehtymisen viivästymisestä ja kasvatusajan pidentymisestä aiheutuvan lisäkustannuksen jakamiseksi jotkut ovat sopineet hiehokohtaisen maksimihinnan. Kokonaishintaan vaikuttaa myös se, miten tehtävät ja vastuut jaetaan osapuolten kesken. Siten yksikäsitteistä hintastandardia ei ole muodostunut.

\footnotetext{
${ }^{4}$ Hiehonkasvattajalla ei ole omaa strategista intressiä eläinaineksen kehittämiseen.
} 


\section{Yhteisnavetta}

Yhteisnavetan osakkaat ovat luopuneet itsenäisistä strategisista tavoitteistaan. He kokivat yritystoiminnan laajentamisen omin voimin liian riskipitoiseksi. Ennen yhteisnavetan perustamista he tuottivat maitoa kukin omassa navetassaan. Strategiseksi tavoitteeksi he asettivat maidontuotannon laajentamisen, jotta yritystoiminnan kannattavuus voidaan turvata. Yhteisnavetta mahdollistaa yksikkökustannusten alentamisen, yrittäjäkohtaisen työtaakan vähentämisen, työstä vapaalle irtautumisen, riskien hallinnan parantamisen sekä vastuun jakamisen ja osaamispääoman kasvattamisen. Yhteisnavettahankkeeseen ryhtymisen taustalla on osakkaiden tuttuus tai aikaisempi yhteistyö kasvinviljelyssä. Yhdessäkään tapauksessa yhteisnavettahanketta ei ollut toteutettu sellaisten henkilöiden kanssa, jotka eivät olleet tunteneet toisiaan jo aikaisemmin.

Merkille pantavaa on, että yhteisnavetat perustettiin suunnilleen samankokoisten maitotilojen kesken, jolloin omaisuus ja oikeudet oli helppo siirtää apporttisiirtoina ja osakkaiden osuudet yhteisnavetasta pysyivät lähes samansuuruisina ilman merkittävien rahasummien liikuttelua. Tällä on merkitystä mm. yhteenkuuluvuuden, työnjaon ja tulonjaon kannalta. Yhteisnavetat perustettiin siten, että pelto, maitokiintiö ja eläimet siirrettiin yhteisnavetan omistukseen tai hallintaan. Tyypillisesti eläimet ja maitokiintiöt siirrettiin yhteisnavetan omistukseen ja pelto vuokrattiin. Jokainen lehmä ja peltohehtaari pidettiin samanarvoisena. Yhteisnavetta rakensi tuotantotilat ja hankki navetan koneet ja kaluston. Tuet hakee yhteisnavetta.

Yhteisnavetan yrityskoko näyttää määräytyvän osakkailta tulleiden resurssien pohjalta. Yksi haastateltu totesi, että eihän me olla laajennettu, on vain pantu yhteen se mitä oli. Yhteisnavetta rakennettiin jonkun osakkaan tilakeskukseen tai sille valittiin logistisesti sopivin paikka. Kasvinviljelyn järjestämisen osalta oli suuria eroja. Yleisin käytäntö on, että osakkaat urakoivat yhteisnavettayhtiölle niin kauan kunnes olemassa olevat koneet on ajettu loppuun, jolloin päätetään uudesta toimintatavasta.

Sosiaalisista tekijöistä korostuvat luottamus, samansuuntaiset tavoitteet ja samantasoinen työnjälki. Luottamuksen osatekijäksi haastateltavat kokivat vastuun jakamisen ja ottamisen sekä toisen tai toisten osapuolten osaamisen. Sosiaalinen vuorovaikutus on tärkeää. Työturvallisuus paranee, kun navetassa ei tarvitse olla yksin. Yhteisnavetan perustamisen lähtökohtana ollut luottamus näyttää ajan myötä pääsääntöisesti säilyneen. Yhdessä yhteisnavetassa sukupolvenvaihdos on ajankohtainen, mikä koettiin haastavaksi ja myös ristiriitoja herättäväksi.

Yhdellekään yhteisnavetalle ei ollut tehty kirjallista, järjestelmällisesti laadittua ja ylläpidettyä pitkän aikavälin toimintasuunnitelmaa, strategiaa. Osakkaiden strateginen ajattelu näyttää olleen samansuuntaista. Siten on ymmärrettävää, että he ovat löytäneet yhteisymmärryksen strategian toteuttamisesta ilman määrämuotoista suunnitelmaa. Pääsääntöisesti yhteisnavettojen yhtiömuotona oli avoin yhtiö. Vain yksi oli maatalousyhtymä. Lainsäädännön muutoksen vuoksi osakeyhtiömuodon valinnan todennäköisyys kasvaa aiempaan verrattuna.

Tulonjako perustuu pääosin osakkaiden työmäärään. Lisäksi osakkaille kertyy tuloa pellon vuokrina, jotka useimmiten on määritetty paikkakunnan markkinahinnan tasolle sekä koneurakoinnista omilla koneilla yhteisnavetalle. Kaikki osakkaat osallistuvat operatiiviseen toimintaan vuorollaan. Heidän on kyettävä huolehtimaan kaikista rutiinitöistä, mikä mahdollistaa kaikille huolettoman vapaaajan. Se oli yksi tärkeimmistä perusteista yhteisnavetan perustamiselle.

\section{Johtopäätökset}

Yhteistyö ja verkostomainen yrittäminen edellyttävät maidontuottajalta tietoista strategista ajattelua, kun hän erilaisia yhteistyömuotoja hyödyntämällä, eri toimijoiden kanssa kumppanuussuhteita rakentamalla ja urakointipalveluita hyödyntämällä hakee mahdollisuutta toteuttaa kustannustehokkuusstrategiaa. Yhteistyön avulla saavutetaan kilpailuetua. Yhteistyön tuloksena resursseihin sitoutuneen pääoman määrä vähenee, investointien käyttöaste kasvaa ja työn hallinta paranee. Yhteistyön myötä toiminta tehostuu ja yksikkökustannukset alenevat, mikä parantaa taloudellista tulosta ja kannattavuutta. Suurtuotannon edut kannustavat yhteistyön aloittamiseen ja verkostoitumiseen. Myös riskien hallinta ja jakaminen koetaan tärkeäksi. Yhteistyön avulla yhteinen osaamispääoma kasvaa. Kukin osakas voi erikoistua tietyille osa-alueille. Yritystä kehitettäessä inhimillisen resurssin, erityisesti osaamisen, tarve kasvaa. Yhteistyöllä on arvo tässäkin (vrt. Spekman, Isabella \& MacAvoy 2000, 7).

Yhteistyö on sopiva ratkaisu, kun lähialueella on potentiaalisia kumppaneita, joiden strateginen ajattelu tukee yhteistyötä ja verkostoitumista. Onnistumisedellytykset paranevat, kun heillä on yhtei- 
nen näkemys yritystoiminnan kehittämisestä eli heidän strateginen ajattelunsa, arvonsa ja asenteensa tukevat yhdessä yrittämistä. Haastateltujen mukaan yhteistyösuhteet ovat olleet sosiaalisesti ja taloudellisesti kestävällä pohjalla.

Tutkitut yhteistyösuhteet perustuvat jo ennen yhteistyön aloittamista syntyneeseen keskinäiseen luottamukseen. Tästä syystä tutkituissa yhteistyösuhteissa ei ollut laadittu yksityiskohtaisia kirjallisia sopimuksia. Haastatellut korostivat suurpiirteisyyttä ja joustavuutta, koska tilanteiden vaihtelun vuoksi kaikista asioista ei kuitenkaan voida sopia tarkasti etukäteen.

\section{Kirjallisuus}

Blomqvist, K. 2002. Partnering in the Dynamic Environment: The Role of Trust in Asymmetric Technology Partnership Formation, Acta Universitatis Lappeenrantaensis 122, Lappeenrannan teknillinen korkeakoulu.

Hakanen, M., Heinonen, U. \& Sipilä, P. 2007. Verkostojen strategiat. Menesty yhteistyössä. Edita, Helsinki. Hirsjärvi, S., Remes, P. \& Sajavaara, P. 2007. Tutki ja kirjoita. 13., osin uud. p. Helsinki: Kustannusosakeyhtiö Tammi.

Johnson, G., Schules K., Whittington, R. 2008. Exploring Corporate Strategy. 8. ed. Prentice Hall, Harlow, England.

Laitila, E., Ryhänen, M., Närvä, M., Sipiläinen, T., Heiskari, M., Jokiaho, S., Ketola, J., Kämäräinen, S., Känsäkoski, H., Palo, A., \& Pieviläinen, A. 2012. Verkostomainen yrittäminen. Teoksessa: M. Ryhänen \& E. Laitila (toim): Yhteistyö ja resurssit maitotiloilla, Verkostomaisen yrittämisen lähtökohtia ja edellytyksiä, Seinäjoen ammattikorkeakoulun julkaisuja B 59: 91-134.

Metsämuuronen, J. 2009. Tutkimuksen tekemisen perusteet ihmistieteissä. Tutkijalaitos. Jyväskylä: Gummerus.

Möller, K., Rajala, A. \& Svahn, S. 2004. Tulevaisuutena liiketoimintaverkot. Johtaminen ja arvonluonti. Teknologiateollisuuden julkaisuja 11/2004. Tammer-Paino Oy, Tampere.

Öhlmér, B., Olson, K. \& Brehmer, B. 1993. Towards a Model of Strategic Decision Making. An Application to Farmers' Adaptation to Deregulation of Agriculture and EC-membership. Institutionen för ekonomi. Rapport 60: 160.

Ryhänen, M., Närvä, M., Sipiläinen, T., Tukeva, A., Kataja, J., Talvilahti, A., Lappalainen, J. \& Nissinen, K. 2011. Toimialan SWOT-analyysi ja johtopäätökset. Teoksessa: M. Ryhänen \& K. Nissinen (toim.) Kilpailukyä maidontuotantoon: toimintaympäristön tarkastelu ja ennakointi. Seinäjoen ammattikorkeakoulun julkaisusarja A. Tutkimuksia 8: 58-74.

SFS-EN ISO 9001. 2008. Laadunhallintajärjestelmät. Vaatimukset. Suomen Standardoimisliitto SFS.

Spekman, R.E., Isabella, L.A. \& MacAvoy, T.C. 2000. Alliance Competence, Maximizing the Value of Your Partnerships. New York: Wiley and Sons Inc.

Ståhle, P. \& Laento, K. 2000. Strateginen kumppanuus - avain uudistumiskykyyn ja ylivoimaan. Ekonomiasarja. WSOY, Helsinki.

Uotila, I. 1989. Liittoutumisen strategiset edut ja miten ne voidaan saavuttaa. Teoksessa S.A.M.I. Oy, S.A.M.I.vuosikirja 1989. Liittoutuminen, Art-Print Oy, Helsinki.

Vesalainen, J. 2007. Yritysyhteistyön malleja. Viitattu 15.11.2013. Saatavana: www.yrittajakoulu.com/yrittäjyyden oppia.

Vesalainen, J. 2002. Kaupankäynnistä kumppanuuteen: Yritystenvälisten suhteiden elementit, analysointi ja kehittäminen. Tampere: Metalliteollisuuden kustannus Oy. 